\title{
Effect of temperature, shearing time and rate of shear on the apparent viscosity of fresh cheeses
}

\author{
J Korolczuk, M Mahaut \\ INRA, Laboratoire de recherches de technologie laitière, 65, rue de Saint-Brieuc, \\ 35042 Rennes Cedex, France
}

(Received 9 January 1989; accepted 25 September 1989)

\begin{abstract}
Summary - The apparent viscosity of market acid-type cheese samples was measured with a coaxial cylinder viscosimeter, in the temperature range 5 to $40^{\circ} \mathrm{C}$. The logarithm of the apparent viscosity was a linear function of the logarithm of the shear rate, of the logarithm of the shearing time and of the reciprocal absolute temperature. The activation energy of flow was about $13 \mathrm{~kJ} / \mathrm{mol}$ for the non-fat cheese, while for the cheese containing $20 \%$ fat in dry matter and for the temperature range between 15 and $20^{\circ} \mathrm{C}$, it increased to $48 \mathrm{~kJ} / \mathrm{mol}$ because of solidification of the fat fraction.
\end{abstract}

acid cheese / texture / apparent viscosity / activation energy of flow

Résumé - Influence de la température, du temps et de la vitesse de cisaillement sur la viscosité apparente de fromages frais. La viscosité apparente de fromages frais du marché a été mesurée avec des viscosimètres à cylindres coaxiaux entre 5 et $40^{\circ} \mathrm{C}$. Le logarithme de la viscosité apparente était une fonction linéaire du logarithme de la vitesse de cisaillement, du logarithme du temps de cisaillement et de l'inverse de la température absolue. L'énergie d'activation d'écoulement était de l'ordre de $13 \mathrm{~kJ} / \mathrm{mol}$ pour un fromage maigre, tandis que pour un fromage contenant $20 \%$ de gras sur sec et pour les températures comprises entre 15 et $20^{\circ} \mathrm{C}$, elle s'élevait à $48 \mathrm{~kJ} / \mathrm{mol}$ en raison de la solidification de la matière grasse.

fromages frais / texture / viscosité apparente / énergie d'activation d'écoulement

\section{INTRODUCTION}

Different methods have been used to evaluate the texture of acid type fresh cheeses. Emmons and Price (1959) measured the firmness of cottage cheese with a Cherry-Burrel wire cutter. An improved version was used by Voisey and Emmons (1966). They found a good correlation ( $r=0.96$ to 0.97 ) between the results obtained by this method and organoleptic evaluations of the cheese texture. 
Daniewski $(1972,1973)$ used an extrusion method to analyse the influence of technological parameters on the consistency of the twarog-type cheese. He found a rectilinear relationship between the consistency index and the water content. The extrusion method was also used by Dunkley and Patterson (1977) and Perry and Carroad (1980a, b). They found linear relation between the total solids and the firmness of cottage cheese.

An uniaxial compression method was used by Lee et al (1978) and Imoto et al (1979) to study the effect of the compression ratio $(20-80 \%)$ on the compression force. They found good correlation ( $r>$ 0.95 ) between sensory evaluations of the hardness of the cream cheese and the compression force. The same method was used by Hori (1982), who found significant effects of the freezing and thawing rates of the cream cheese on the force at yielding point, the energy to cause yielding, the stiffness and the modulus of deformability.

Corrieu and Ferret (1981) and Corrieu et al $(1982,1983)$ found linear relationships between the apparent viscosity and the dry matter content of the low-fat fresh cheese. They proposed an in-line built tube viscosimeter to control the dry matter content during the production of the acidtype cheeses. Mahaut et al (1982, 1986) measured the apparent viscosity of acidtype fresh cheeses obtained by ultrafiltration from cow's and goat's milk. They found linear relationships between the logarithm of the apparent viscosity and the logarithm of the rate of shear $(r=1)$ and between the logarithm of the apparent viscosity and total protein content $(r=0.96)$. Bogdanovskii et al (1985) observed a decrease of the yield value of a twarog-type cheese, measured by the penetrometric method, with an increase in pumping pressure and temperature.
Low solids (15-20\%), low protein content (7.5-9.5\%), acid-type fresh cheeses, as produced in France, have a very soft consistency. They are semi-liquids rather than semi-solids. For this reason, the application of the viscosimetric method is quite justified.

The aim of this work was to analyse the relations between the apparent viscosity of acid-type cheeses and the shearing time, the rate of shear and temperature.

\section{MATERIALS AND METHODS}

Samples of acid-type fresh cheeses : Silhouette (Yoplait, Paris, France) and Jockey (Gervais Danone, Levallois, France) were purchased in a local supermarket. The dry matter, fat and protein contents were determined by using standard methods (Serres et al, 1973).

Thermostated $\left(5\right.$ to $40^{\circ} \mathrm{C} \pm 0.1^{\circ} \mathrm{C}$ ), coaxialcylinder viscosimeters, type Rheomat-30 and Low-shear-30 (Contraves, Zurich, Switzerland), were used to measure the apparent viscosity of fresh cheese at a rate of shear ranging between $1.7 \times 10^{-4}$ and $2.0 \times 10^{-3} \mathrm{~s}^{-1}$ (Low-shear-30) and between 9 and $482 \mathrm{~s}^{-1}$ (Rheomat-30). The internal/external diameters of the viscosimeter cylinders were $25 / 27 \mathrm{~mm}$ (Rheomat-30) and $3 /$ $12 \mathrm{~mm}$ (Low-shear-30). The viscosimeters were calibrated with a standard fluid having the viscosity of $18.78 \mathrm{~Pa} . \mathrm{S}^{\circ}$ at $20^{\circ} \mathrm{C}$ (VEB MLW, Sitz Freital, GDR). The output signal of the viscosimeter was digitalized by the analog digital converter, type CAN-1612M1 (MID, Paris, France), having a resolution of $0.024 \%$ and connected to an Apple II plus microcomputer (Apple Computer Inc., Cupertino, CA, USA). For data acquisition, a modified program, described previously (Korolczuck et al, 1985), was used. Approximately, 2000 averages of 10 measurements of the output signal of the viscosimeter, recorded every $1 \mathrm{~s}$ together with the time readings from Apple Clock (Mountain Computer Inc., Santa Cruz, CA, USA) were stored in the computer's memory and were then recorded on a floppy disc.

The cheese samples were stored overnight at $5{ }^{\circ} \mathrm{C}$. Samples were put into the cylinder of 
the viscosimeter and kept in a water bath at 5 , $10,15,20,30$ or $40^{\circ} \mathrm{C}$ for half-an-hour without rotation. The data acquisition of the viscosity evolution during measurement was started simultaneously with the rotation of the cylinder. Apparent viscosity was recorded over $2000 \mathrm{~s}$. For each rate of shear and each temperature, a new part of the same sample was put into the cylinder. Each experiment was repeated 5 times.

\section{RESULTS AND DISCUSSION}

The viscosity of acid-type cheeses decreased with an increase of the rate of shear and of the shearing time (fig 1). Their relationships are typical for so-called pseudo-plastic bodies. They become linear when plotted on logarithmic scales :

$$
\begin{aligned}
\log \eta_{\mathrm{t}, \mathrm{D}}= & \log \eta_{1,1}+A \cdot \log D+B \cdot \log t \\
& +C \cdot \log D \cdot \log t
\end{aligned}
$$

where : $\eta_{t, D}=$ apparent viscosity (mPa.s) for a given shearing time $(t)$ and the rate of strain $(D) ; \eta_{1,1}=$ apparent viscosity value (calculated by the least-squares method) for $D=1 \mathrm{~s}^{-1}$ and $t=1 \mathrm{~s} ; A=$ increase of the logarithm of the viscosity for unit increase of the logarithm of the rate of strain $(D) ; D=$ rate of strain $\left(\mathrm{s}^{-1}\right) ; B=$ increase of the logarithm of the viscosity for unit increase of the logarithm of the shearing time $(t) ; t=$ shearing time $(s) ; C=$ interaction coefficient between the rate of strain and the shearing time.

In the example given in Fig. 1, the values of $\log \eta_{1,1}, A, B$ and $C$ were respectively $4.32,-0.569,-0.0529$ and 0.0169 . For 36 samples analysed of 2 types of fresh cheese (Silhouette and Jockey), the average coefficient of variation of the apparent viscosity for $t=1 \mathrm{~s}$ and $D=1 \mathrm{~s}^{-1}$ $\left(\eta_{1,1}\right.$ in eqn. (1)), calculated for 5 repetitions of each experiment, was below $2 \%$, while that of the coefficients $A$ and $B$ was below $10 \%$. This shows that the results obtained by the viscosimetric method are quite reliable, which has already been proved by Corrieu and Ferret (1981), Corrieu et al $(1982,1983)$ and Mahaut et al $(1982,1986)$.

It appears that the apparent viscosity depended much more on the rate of shear than on the shearing time, but the effect of time cannot be neglected. Figure 1 also shows that the rate of the rheodestruction depends to some extent on the rate of shear and it increases with an increase of the rate of shear. Such behaviour could be explained by the continuous destruction of the cheese structure caused by prolonged shearing. Semi-liquid acid-type fresh cheeses such as the ones used in this work may have a similar structure to that of stirred yoghurt, i.e. composed of irregular

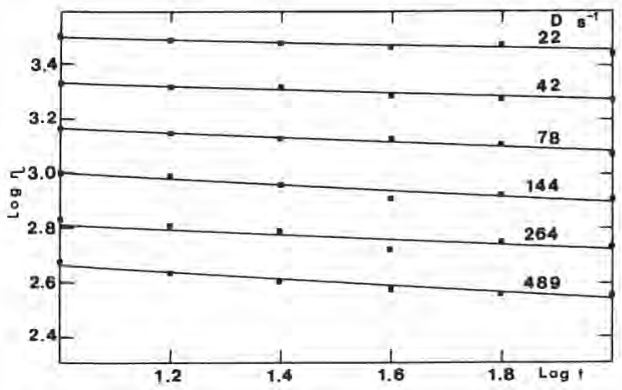

Fig 1. Evolution of the logarithm of the apparent viscosity ( $\mathrm{mPa} \cdot \mathrm{s})$ as a function of the logarithm of the shearing time ( $t$ in $s$ ) and of the logarithm of the rate of strain $\left(D\right.$ in $\left.\mathrm{s}^{-1}\right)$.

Experimental conditions: Market fresh cheese (Silhouette) with $0 \%$ fat, $8.8 \%$ protein and $14.6 \%$ dry matter. Viscosity was measured at $20^{\circ} \mathrm{C}$.

Evolution du logarithme de la viscosité apparente (mPa.s) en fonction du logarithme du temps de cisaillement ( $t$ en s) et du logarithme de la vitesse de cisaillement ( $\mathrm{D}$ en $\mathrm{s}^{-1}$ ).

Conditions expérimentales : fromage frais du commerce (Silhouette) contenant $0 \%$ de matière grasse, $8,8 \%$ de protéines et $14,6 \%$ de matière sèche. La viscosité a été mesurée à $20^{\circ} \mathrm{C}$. 
protein particles of variable dimensions (Allan-Wojtas and Kalab, 1984). Scanning electron micrographs (Glaser et al, 1979; Kalab et al, 1983) show that the inside structure of acid-type curd of a cottage cheese or acid gel of yoghurt consists of an open, loose network of casein micelles aggregated in branched chains and coarse clusters which form compartments of irregular shape and dimensions. Such a structure is relatively fragile and when subjected to shearing, it breaks. The observed diminishing stress corresponds to the decrease of an average hydrodynamic diameter of protein aggregates, which is a function of the shearing time and of the rate of shear.

The same type of so-called power law relations between the stress or the apparent viscosity and the rate of strain was observed by Corrieu et al (1982) for the rate of strain range between 4 and $60 \mathrm{~s}^{-1}$ and by Mahaut et al (1982) for 81 to $1312 \mathrm{~s}^{-1}$.

Temperature greatly influences the viscosity of the fresh cheese (Fig 2). This relation could be described by an Arrheniustype of equation (Van Wazer et al, 1963; Rha and Pradipasena, 1986) :

$$
\log \eta_{T, t}=\log \eta_{\infty, 1}+E / R T+B \cdot \log t
$$

where $\eta_{\mathrm{T}, \mathrm{t}}=$ apparent viscosity $(\mathrm{mPa} \cdot \mathrm{s})$ for a given temperature $(T)$ and shearing time $(t) ; \eta_{\infty, 1}=$ hypothetical level of the apparent viscosity (mPa.s) for the temperature $T=\infty$ and the shearing time $\mathrm{t}=1 \mathrm{~s} ; E=$ apparent activation energy of flow $(\mathrm{J} / \mathrm{mol})$; $R=$ gas constant $(8.315 \mathrm{~J} / \mathrm{K} \cdot \mathrm{mol}) ; T=$ temperature $(\mathrm{K})$.

For the example given in Fig. 2, the values of the $\log \eta_{\infty, 1}, E$ and $B$ were respectively $-2.428,13.38 \mathrm{~kJ} / \mathrm{mol}$ and -0.0533 . For lower temperatures, the texture destruction was slower. The same tendency of influence of temperature and shearing on the consistency of acid-type cheeses was observed by Bogdanovskii et al. (1986) by the penetrometric method, and Mahaut et al $(1982,1986)$ by the viscosimetric method. Calculated from the results of Mahaut et al (1982), the activation energy of flow was about $22 \mathrm{~kJ} / \mathrm{mol}$ independently of the rate of shear ( 81 to $1312 \mathrm{~s}^{-1}$ ), for the non-fat acid-fresh cheese containing $6.5 \%$ protein.

The logarithm of the viscosity of a nonfat, fresh cheese was a function of the rate of shear and temperature (Fig 3). It can be described by the following relation :

$$
\begin{aligned}
\log \eta_{1, T, D} & =\log \eta_{1, \infty, 1}+A \cdot \log D \\
& +E / R T(3)
\end{aligned}
$$

where $\eta_{1, T, D}=$ apparent viscosity after $1 \mathrm{~s}$ of shearing (calculated by the least squares method), for given temperature $(T)$ and the rate of shear $(D) ; \eta_{1, \infty, 1}=$ value of $\eta_{1, T, D}$ for $T=\infty$ and $D=1 \mathrm{~s}^{-1}$ (calculated by the least-squares method);

$A, D, E, R$ and $T$ are the same as in eqs. (1) and (2).

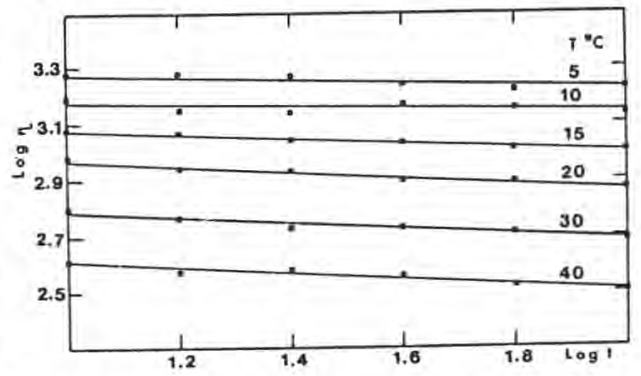

Fig 2. Logarithm of the apparent viscosity $\left(\eta_{a}\right.$ in $\mathrm{mPa}$-s) of a fresh cheese sample, for the rate of strain $D=141 \mathrm{~s}^{-1}$, as a function of temperature ( $T$ in ${ }^{\circ} \mathrm{C}$ ) and of the logarithm of the shearing time ( $t$ in $s$ ). Cheese sample was the same as in Fig 1.

Le logarithme de la viscosité apparente $\left(\eta_{a}\right.$ en $\mathrm{mPa} \cdot \mathrm{s})$ d'un échantillon de fromage frais, pour une vitesse de cisaillement $\mathrm{D}=141 \mathrm{~s}^{-1}$, en fonction de la température et du logarithme du temps de cisaillement (t en s). L'échantillon de fromage était le méme que dans la Fig 1. 


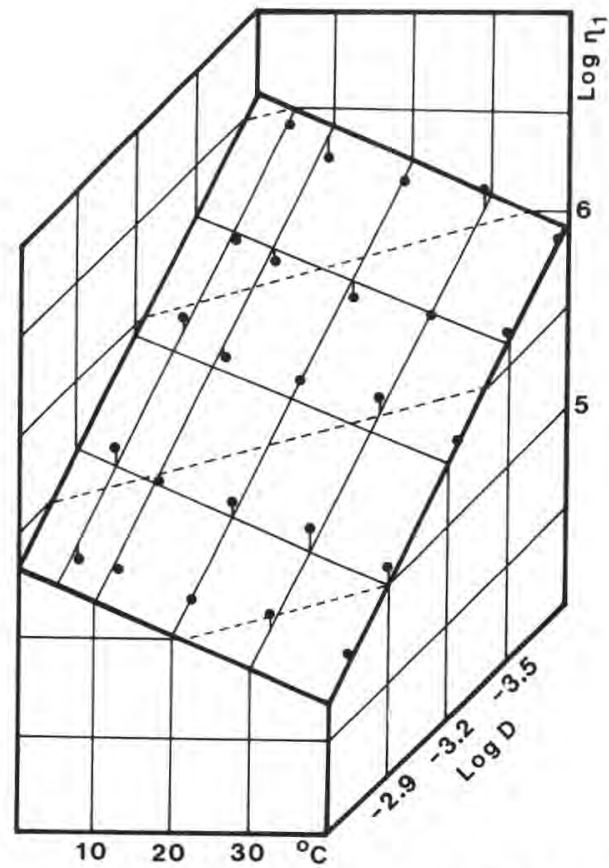

Fig 3. Logarithm of the apparent viscosity of a fresh cheese sample, after $1 \mathrm{~s}$ of shearing $\left(\eta_{1}\right.$ in $\mathrm{mPa}$.s, calculated by the least-squares method), as a function of temperature $\left(T\right.$ in $\left.{ }^{\circ} \mathrm{C}\right)$ and of the logarithm of the rate of strain ( $D$ in $s^{-1}$ ).

Sample: market fresh cheese (Silhouette) with $0 \%$ fat, $8.6 \%$ total proteins and $14.0 \%$ dry matter. Le logarithme de la viscosité apparente d'un échantillon de fromage frais, après 1 s de cisaillement ( $\eta_{1}$ en mPa.s, calculé par la méthode des moindres carrés), en fonction de la température $\left(\mathrm{T}\right.$ en $\left.{ }^{\circ} \mathrm{C}\right)$ et du logarithme de la vitesse de cisaillement $\left(D\right.$ en $\left.s^{-1}\right)$. Echantillon : fromage frais du commerce (Silhouette), contenant $0 \%$ de matière grasse, $8,6 \%$ de protéines et $14,0 \%$ de matière sèche.

The values of $\log \eta_{1, \infty, 1}, E$ and $A$ for the example given in fig 3 were $-2.991,13.1$ $\mathrm{kJ} / \mathrm{mol}$ and - 1.012. No interaction between the rate of strain and temperature was observed. Because of the lower rate of shear applied in this experiment, the viscosity level was much higher than in figs 1 and 2, for the same type of cheese and about the same protein content, but the activation energy of flow was about the same for both ranges of the rate of shear. This means that the activation energy of flow does not depend on the rate of shear.

A cheese sample having $20 \%$ fat in total solids (fig 4) displayed slightly different behaviour. Between 5 and $15^{\circ} \mathrm{C}$ and 20 and $40^{\circ} \mathrm{C}$ the rate of decrease of the apparent viscosity was much lower than between 15 and $20^{\circ} \mathrm{C}$. This difference may be explained by the fat melting at over $15^{\circ} \mathrm{C}$. Because of this, the activation energy of flow was on average $18.3 \pm 1.8 \mathrm{~kJ} / \mathrm{mol}$ for the temperature range between 5 to $15^{\circ} \mathrm{C}$ and 20 to $40^{\circ} \mathrm{C}$ and it was $47.5 \pm 4.0 \mathrm{~kJ} /$ $\mathrm{mol}$ for 15 and $20{ }^{\circ} \mathrm{C}$. The coefficient $A$ from eqn. (2) was -1.033 in fig 4 , i.e. it was the same as for the non-fat cheese (fig 3 ). It should be pointed out that the value of the coefficient $A$ should not be lower than -1. For $A=-1$ the stress is independent of the rate of shear, which is a typical situation for so-called plastic flow. The experimental values of the coefficient $A$ were within the limits of the experimental error equal to -1 (figs 3 and 4 ) for the relatively low rate of shear $(0.00017<D<0.0025$ $\left.\mathrm{s}^{-1}\right)$, while for the higher rate of shear $(9<$ $D<482 \mathrm{~s}^{-1}$ ) $A=-0.57$, typical of socalled pseudo-plastic bodies. It is possible that for a much higher rate of shear range, the cheese samples would behave as a Newtonian liquid $(A=0)$.

\section{CONCLUSIONS}

Summarizing our experiments, it could be concluded that, compared to other methods already used to quantify the consistency of fresh cheeses, the viscosimetric method appears to be quite reliable. This method allows one to study the shear stress and the apparent viscosity as a 


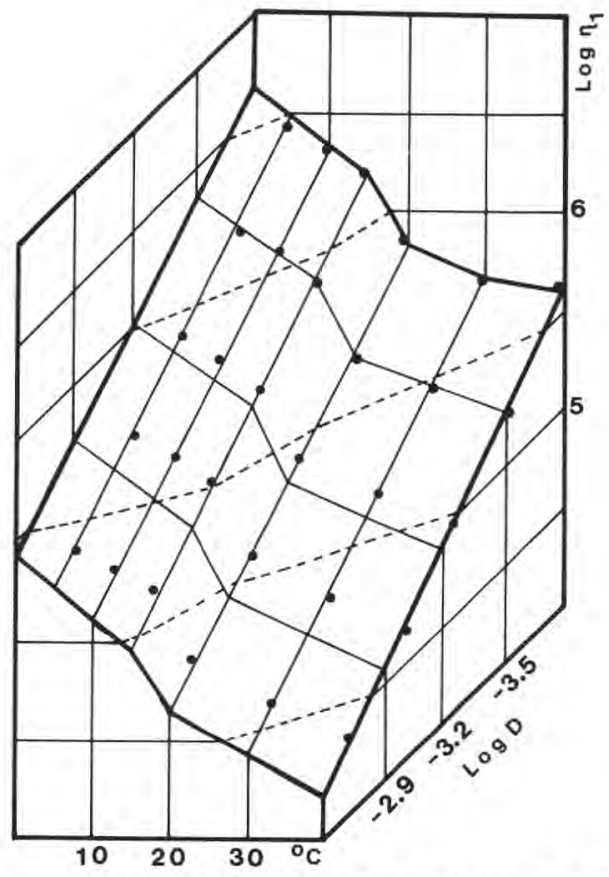

Fig 4. Logarithm of the apparent viscosity of a fresh cheese sample, after $1 \mathrm{~s}$ of shearing $\left(\eta_{1}\right.$ in $\mathrm{mPa} \cdot \mathrm{s}$, calculated by the least-squares method), as a function of temperature $\left(T\right.$ in $\left.{ }^{\circ} \mathrm{C}\right)$ and of the logarithm of the rate of strain $(D$ in s-1).

Sample: market fresh cheese (Jockey) having $20 \%$ fat in dry matter, $8.5 \%$ total proteins and $17.8 \%$ dry matter.

Le logarithme de la viscosité apparente d'un échantillon de fromage frais, après $1 \mathrm{~s}$ de cisaillement ( $\eta_{1}$ en mPa॰s, calculé par la méthode des moindres carrés), en fonction de la température $\left(T\right.$ en $\left.{ }^{\circ} \mathrm{C}\right)$ et du logarithme de la vitesse de cisaillement ( $\mathrm{D}$ en $\mathrm{5}^{-1}$ ). Echantillon : fromage frais du commerce (Jockey), contenant 20\% de gras sur sec, $8,5 \%$ de protéines et $17,8 \%$ de matière sèche.

function of the shearing time, rate of shear, temperature and eventually other physical, chemical and technological parameters of cheese preparation. Its precision is quite good $(2-10 \%)$ and it needs only relatively simple equipment. Knowledge of the stress or viscosity evolution as a function of the rate of shear, time and temperature as function of the rate of shear, time and temperature is of great importance for process designers and technologists.

\section{REFERENCES}

Allan-Wojtas P, Kalab M (1984) A simple procedure for preparation of stirred yoghurt for scanning electron microscopy. Food Microstruct 3, 197-198

Bogdanovskii VB, Fridenberg GV, Gorbatov AV, Karslyants AP, Zimin AF, Kosoi VD (1985) Preparation of twarog for manufacture of speciality twarog products under conditions of transport under pressure. Moloch Prom (5), 25-27. Cit. after Dairy Sci Abstr 48, (1986) 656, Abstr. No. 5536

Corrieu G, Ferret R (1981) Un nouveau procédé pour mesurer et contrôler l'extrait sec des fromages frais maigres. Tech Lait 960, 11-13

Corrieu G, Lalande M, Fissette A (1982) Corrélation entre la teneur en matière sèche du fromage frais maigre et sa viscosité apparente mesurée en ligne. Sci Aliments 2, 4154

Corrieu G, Maingonnat JF, Ferret R (1983) Un viscosimètre industriel pour la caractérisation en continu des produits alimentaires de viscosité élevée. Ind Alim Agric 100, 235-240

Daniewski P (1972) Determination of consistency of skim-milk acid twarog by the shear method. Rocz Inst Przem Mlecz 14, (3), 4348

Daniewski P (1973) Effect of processing conditions on consistency of low-fat twarog. Rocz Inst Przem Mlecz 15, (2), 107-115

Dunkley WL, Patterson DR (1977) Relations among manufacturing procedures and properties of cottage cheese. J Dairy Sci 60 1824-1840

Emmons DB, Price WV (1959) A curd firmness test for cottage cheese. J Dairy Sci 42, 553556

Glaser J, Carroad PA, Dunkley WL (1979) Surface structure of cottage cheese curd by electron microscopy. J Dairy Sci 62, 10581068 
Hori T (1982) Effects of freezing and thawing green curds before processing on the rheological properties of cream cheese. J Food Sci $47,1811-1817$

Imoto EM, Lee CH, Rha C (1979) Effect of compression ratio on the mechanical properties of cheese. J Food Sci 44, 343-345

Kalab M, Allan-Wojtas P, Phipps-Todd BE (1983) Development of microstructure in setstyle nonfat yoghurt. A review. Food Microstruct 2, 51-66

Korolczuk J, Mahaut M (1988) Studies on acid cheese texture by a computerized, constant speed, cone penetrometer. Lait 68, 349-362

Korolczuk J, Roignant M, Maubois JL (1985) Computer data acquisition of sinusoidally varying stress and strain. J Texture Stud 16, 129-142

Lee CH, Imoto EM, Rha C (1978) Evaluation of cheese texture. J Food Sci 43, 1600-1605

Mahaut M, Korolczuk J, Pannetier R, Maubois JL (1986) Eléments de fabrication de fromage de type pâte molle de lait de chèvre à caractère lactique par ultrafiltration de lait acidifié et coagulé. Tech Lait Market 1011, 2428

Mahaut M, Maubois JL, Zink A, Pannetier R, Veyre R (1982) Eléments de fabrication de fromages frais par ultrafiltration sur membrane de coagulum de lait. Tech Lait 961, 913

Perry C, Carroad PA (1980a) Influence of acid related manufacturing practices on properties of cottage cheese curd. J Food Sci 45, 794797

Perry CA, Carroad PA (1980b) Instrument of texture of small curd cottage cheese and comparison to sensory evaluation. $J$ Food Sci $45,798-801$

Rha C, Pradipasena P (1986) Viscosity of proteins. In: Functional Properties of Food Macromolecules. (Mitchell JR, Ledward DA, ed.) Elsevier Applied Science, London and New York, pp 79-120

Serres L, Amariglio S, Petransxiene D (1973) Contrôle de la qualité des produits laitiers. In: Analyse physique et chimique. Tome 1. Edition du Ministère de l'Agriculture. Direction des Services Vétérinaires $\mathrm{p}$ VIII/1 - VII/7

Van Wazer JR, Lyons JW, Kim KY, Colwell RE (1963) Viscosity and Flow Measurement. A Laboratory Handbook of Rheology. Interscience. New York and London

Voisey PW, Emmons DB (1966) Modification of the curd firmness test for cottage cheese. $J$ Dairy Sci 49, 93-96 